\title{
Amulets and the Material Interface of Beliefs in Seventeenth-Century Prague Burgher Homes
}

\author{
Suzanna Ivanič
}

This chapter shows how amulets were part of a broad arsenal of religious objects that helped early modern men and women negotiate the divine in daily life. The emphasis here is on understanding amulets specifically as 'religious' objects, and as artefacts that acted as a material interface between religion, medicine and 'folk' belief. Research has shown that from the perspective of the early modern laity stark divisions between religion and magic or superstition were largely absent from daily life. ${ }^{1}$ Spells have been found bound into French religious prayer books, for example, and 'popular' healing rituals in southern Italy incorporated prayers and invocations. ${ }^{2}$ This chapter builds on these earlier studies to explore how small amulets kept at home and used in everyday contexts reveal that these were not just discrete beliefs held simultaneously, but deeply interconnected ones. This material perspective can help recalibrate our understanding of the spiritual world of early modern men and women, and cast light onto a lived belief system that often slips from the textual record.

Amulets were exceptionally popular items owned by men and women of all social strata in early modern Europe. However, so far they have only been treated as marginal to history. They form side notes to studies of magic, superstition or enchantment. ${ }^{3}$ They are referred to in specialist works on so-called 'magical

1 Geertz H., "An Anthropology of Religion and Magic, I", Journal of Interdisciplinary History 6 (1975) 71-89 and Thomas K., "An Anthropology of Religion and Magic, II", Journal of Interdisciplinary History 6 (1975) 91-109; Tambiah S., Magic, Science, Religion, and the Scope of Rationality (Cambridge: 1990) 23, 31; Kieckhefer R., "The Specific Rationality of Medieval Magic", The American Historical Review 99, 3 (1994) 813-836: 836; Clark S., Thinking with Demons: The Idea of Witchcraft in Early Modern Europe (Oxford: 1997) 458.

2 Reinburg V., French Books of Hours: Making an Archive of Prayer, c.1400-16oo (Cambridge: 2011) 133-135; Gentilcore D., From Bishop to Witch: The System of the Sacred in Early Modern Terra d'Otranto (Manchester: 1992) 131, 177.

3 Thomas K., Religion and the Decline of Magic: Studies in Popular Beliefs in Sixteenth and Seventeenth Century England (London: 1979 [1971]) 224-225; Cameron E., Enchanted Europe: Superstition, Reason, and Religion, 1250-1750 (Oxford: 2010) 51-52.

(C) SUZANNA IVANIČ, 2019 | DOI:10.1163/9789004375888_012

This is an open access chapter distributed under the terms of the prevailing CC-BY-NC-ND License at the time of publication. 
jewels' that focus on the use of precious stones in healing and folklore. ${ }^{4}$ In largest number, they are featured in museum catalogues or studies of jewellery. ${ }^{5}$ The most comprehensive volume dedicated to amulets, Amulett und Talisman: Erscheinungsform und Geschichte [Amulet and Talisman: Manifestation and History], was published in 1966 by the German folklorists Liselotte Hansmann and Lenz Kriss-Rettenbeck. ${ }^{6}$ This work catalogued hundreds of objects and images relating to amulets and talismans from antiquity to the nineteenth century, focusing on examples from the early modern period. In doing so, it revealed how the early modern period was an exceptional age for amulets. Categorizing these artefacts into those made from stones, organic matter and animal parts and those fashioned into specific symbols or signs, the work set them firmly within the context of alchemy and magic. Overall, the existing literature has treated amulets as belonging to the realm of the superstitious, folkloric or magical. Their importance to understanding lived religion has, however, been neglected.

To examine how amulets fitted into a belief system in this period, this research focuses on seventeenth-century Prague. This central European city presents the ideal environment for such a study. Firstly, over the course of a century, the population transformed from primarily Protestant to overwhelmingly Catholic owing to recatholicization led by Habsburg rulers from $1620 .{ }^{7}$ It thus allows for confessional nuances to be taken into account. Secondly, from 1577 to 1612, Prague was the seat of the Holy Roman Empire under the Habsburg

4 Evans J., Magical Jewels of the Middle Ages and the Renaissance, particularly in England (Oxford: 1922); Thorndike L., A History of Magic and Experimental Science (New York: 192358); Trachtenberg J., Jewish Magic and Superstition: A Study in Folk Religion (Philadelphia: 2004 [1939]) 132-152; Cherry J., "Healing through Faith: The Continuation of Medieval Attitudes to Jewellery into the Renaissance", Renaissance Studies 15, 2 (2001) 154-171; Blaen T., Medical Jewels, Magical Gems: Precious Stones in Early Modern Britain: Society, Culture and Belief (Crediton: 2012).

5 Kunz G., The Magic of Jewels and Charms (London: 1915); Kunz G., Rings for the Finger (Philadelphia: 1917); Kunz G., The Curious Lore of Precious Stones (London: 1918); Oman C., Victoria and Albert Museum Catalogue of Rings 1930 (Ipswich: 1993); Ettlinger E., "British Amulets in London Museums", Folklore 50, 2 (1939) 148-175; Das Amulett. Die Magie des Schmucks (Kataloge des Museums- und Kulturvereins Schloss Albeck Nr. 1) (Sirnitz: 1994); Tait H. (ed.), Seven Thousand Years of Jewellery (London: 1986); Lightbown R.W., Mediaeval European Jewellery (London: 1992); Scarisbrick D., Rings: Symbols of Wealth Power and Affection (New York: 1993); Scarisbrick D., Tudor and Jacobean Jewellery (London: 1995); Scarisbrick D., Rings: Jewelry of Power, Love and Loyalty (London: 2007).

6 Hansmann L. - Kriss-Rettenbeck L., Amulett und Talisman. Erscheinungsform und Geschichte (Munich: 1966).

7 See further, Louthan H., Converting Bohemia: Force and Persuasion in the Catholic Reformation (Cambridge: 2009). 
Rudolf II (1552-1612). In Prague, Rudolf cultivated a court environment famed for hosting natural philosophers, alchemists and 'magicians', including John Dee, Edward Kelley, Michael Maier, and, briefly, Giordano Bruno. ${ }^{8}$ Prague became a city imbued with a fascination for transforming materials and gaining access to natural powers.

To investigate the use of amulets in daily life in early modern Prague, this research examines evidence from inventories across the century, alongside extant objects, and treatises on natural philosophy. ${ }^{9}$ The first part of the chapter shows how amulets were used and perceived in relation to standard devotional objects, such as prayer beads, crucifixes and Agnus Dei, in the context of the Prague inventories. It reveals how Protestants and Catholics participated in shared practices involving amulets to negotiate divine power in their daily lives. The second part of this chapter focuses on natural philosophy and the materiality of amulets made from stone or animal matter to establish how amulets fitted into a 'unified system' or cosmology in which God had ultimate power over the workings of the world. It argues that the widespread use of amulets by Prague burghers shows that men and women of all social strata engaged in an early modern worldview in which the natural world was infused with divine power.

\section{$1 \quad$ Amulets and Devotional Objects}

Items such as heart-shaped crystal pendants, stones and animal teeth set in silver appear in the inventories of early modern men and women in Prague. They belonged not only to the urban elite but also to artisans and burghers of modest wealth. Even more frequently, 'amuletic' materials like gems as well as coconut shell and horn were integrated into jewellery or devotional objects such as prayer beads or crucifixes. In spite of substantial evidence for the possession of amulets and amuletic materials, there is no mention of the word 'amulet' or 'charm' in the Prague inventories. ${ }^{10}$ These tiny and often inconspicuous items

8 Evans R.J.W., Rudolf II and his world: a study in intellectual history, 1576-1612 (Oxford: 1973) 196-242.

9 I use evidence from a sample of 168 inventories from Prague taken at intervals of five years between 1600 and 1700, which I have analysed as part of a wider project to examine religious materiality: Ivanič S., Religious Materiality in Seventeenth-Century Prague, Ph.D. dissertation (University of Cambridge: 2015).

10 On this point and its significance, as well as further examination of what might be considered an 'amulet', see Ivanič S., "Amulets: A Material Clue to the History of Lived Religion", $V \& A$ Online Journal (forthcoming); further comparative research would be fruitful here: 
that were kept safely in jewellery boxes, cupboards and chests of clothes were used for a matter of utmost importance: they provided a means for their owners to negotiate the exigencies of daily life. Amulets and amuletic materials were employed for healing and protection against physical and psychological dangers.

Evidence in the Prague inventories suggests that amulets and amuletic materials were part of a wide spectrum of items, not limited to devotional objects, that could be used to interact with the divine. They were often kept alongside or integrated with what might be called more traditional 'religious' items. ${ }^{11}$ For example, the 1635 inventory of Kúndrat Šteffenaúr, a court clockmaker originally from Switzerland, noted how he kept 'two silver crosses' and 'two pieces of ivory hand set in silver' in a chest. ${ }^{12}$ This entry for 'ivory hand' related to small charms made out of ivory that were carved into particular hand gestures. A simple extant example of such an object is held in the British Museum [Fig. 10.1]. The gesture made manifest in this case is the mano figa-a closed fist with the thumb clasped between the index and middle fingers - that was commonly employed to ward off the evil eye and to protect fertility. ${ }^{13}$ There was no attempt to hide amulets from the official scribe during the process of making the inventory, indicating that these items were likely to have been considered legally acceptable possessions across the period in spite of their association with superstition at the ecclesiastical level. ${ }^{14}$ Even at the end of the century, in

Italian inventories of a similar period, for example, also do not use any such word to denote amulets (with thanks to Irene Galandra for this observation).

11 For discussion of what a 'religious object' is, see Ivanič S., "Early modern religious objects and materialities of belief", in Richardson C. - Hamling T. - Gaimster D. (eds.), Routledge Handbook of Material Culture in Early Modern Europe (Abingdon: 2016) 322-337, here 333-334.

12 Kúndrat Šteffenaúr (New Town, 1635), Archiv hlavního města Prahy (AHMP) Sbírka rukopisů, rkp. č.1214, fol. 199v.

13 Kemnitz E.-M. von, "Porous Frontiers of the Hand Symbol", in Silva Tavim J.A. - Lopes de Barros M.F. - Lubia Mucznik L. (eds.), In the Iberian Peninsula and Beyond: A History of Jews and Muslims (15th-17th Centuries) vol. 2 (Newcastle: 2015) 258-70; Hansmann - KrissRettenbeck, Amulett und Talisman 192-207; Hildburgh W., "Notes on some Contemporary Portuguese Amulets", Folklore 19, 2 (1908) 213-24.

14 Further research is needed to understand to what extent 'amulets' were condemned by ecclesiastical authorities in Prague in this period. Two treatises written by Jesuits in the late seventeenth century include passages against talismans, but it is unclear to what extent this message reached the laity or led to eradicating amulets from lay possessions; see Šteyer Matěj, Postylla katolická na dvě částky rozdělená nedělní i sváteční, aneb Vejkladové na evangelia [Catholic postil in two parts regarding Sundays and Holy Days, and a commentary on the Gospels] (Prague, Universitatis Carolo-Ferdinandeae: 1691) and Chanovský Albrecht, Správa křestanská s krátkým výkladem podstatnějších věcí [Christian administration with a short explanation of the most essential things] (Prague, Universitatis 


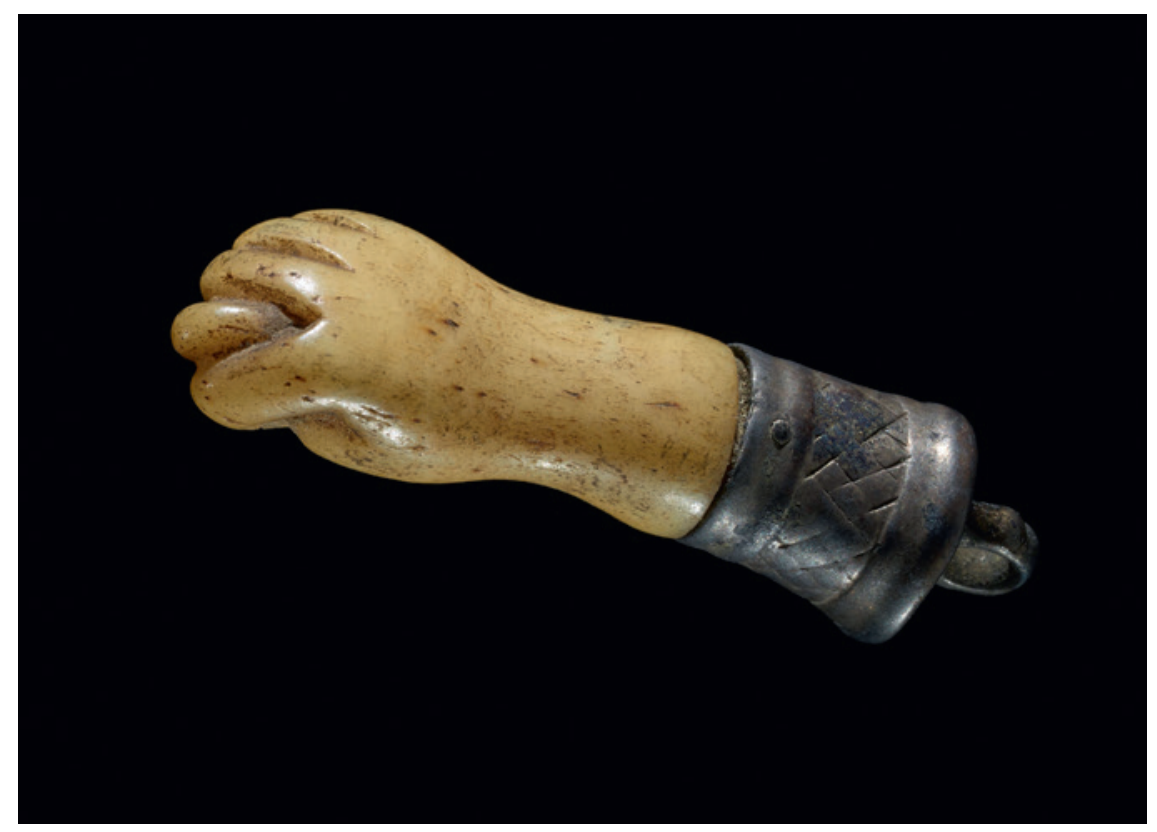

FIGURE 10.1 Ivory hand amulet (seventeenth to eighteenth centuries). Ivory, silver, $38 \mathrm{~mm}$. British Museum (2003,0331.9)

IMAGE (C) THE TRUSTEES OF THE BRITISH MUSEUM

1680, Lydmilla Scoliasterová owned a 'tooth in a silver setting' as well as bibles, Alžběta Humplová owned a wolf's tooth on a necklace and an engraving of the Virgin Mary, and the wig-maker Martin Klockhon owned a wolf's tooth in silver setting along with crucifixes and medals with Christ's image. ${ }^{15}$ In 1700 , amongst numerous Catholic devotional items including religious pictures, books, crucifixes, a reliquary and an altar, Veronika Dirixová owned a 'snake tongue in silver setting' and a 'wolf's tooth in a similar setting' amongst her jewellery. ${ }^{16}$ 'Snake's tongues' - which were in fact fossilized sharks' teeth - had been used since the medieval period for detecting poison. ${ }^{17}$ Inventorial information alone does not explicitly reveal how amulets were treated by their owners, but it does show

Carolo-Ferdinandeae: 1676). See analysis in Mikulec J., "Pověra mezi barokem a osvícenstvím: Zvonění na mraky jako ochranná praktika I zavrženíhodný nešvar”, Folia Historica Bohemica 28, 2 (2013) 259-77.

15 Lydmilla Scoliasterová (New Town, 1680), AHMP 1195, fol. 240v; Alžběta Humplová (Old Town, 1679/8o), AнмP 1177, fol.6o6v; Martin Klockhon (Old Town, 1680), AHмP 1178, fol. 219v.

16 Veronika Dirixová (Old Town, 1700), AHмP 1179, fol. 394v.

17 Lightbown, Mediaeval European Jewellery 237. 
that in numerous instances they were kept in close proximity to devotional objects, and thus indicates at the very least that there was little discomfort with the intimate association among these varied items.

Amuletic materials were also integrally combined with devotional objects. Inventories from both ends of the century reveal that Prague burghers owned prayer beads that were made from amuletic materials. In 1600 Mandelena Hvězdová owned a paternoster made of horn, which may have been meant to draw on the healing properties of the material that were thought to counteract poison. Alongside her numerous Catholic objects in 1700, Veronika Dirixová also owned rosary beads that were made of coconut shell, which was another material that was believed to protect against poison. ${ }^{18}$ These inventories reveal how prayer beads could be made out of materials that allowed the owner to draw simultaneously on the material's apotropaic qualities whilst praying. This practice has been noted in the Italian context, where amber and coral beads were regularly noted in inventories, were depicted in paintings, and also survive as extant examples in museums. ${ }^{19}$ The Prague inventories have so far revealed that - where any material is described - silver was the most common material from which prayer beads were made, followed by so-called 'black' beads (possibly made of painted or varnished wood). However, the occasional references to potentially powerful materials, such as amber and coral and singular mentions of horn and coconut shell, as above, are significant. In such items, the amuletic power was tied inextricably, and materially, to the devotional object.

A number of further examples also reveal that prayer beads might be strung together with charm-like objects. ${ }^{20}$ Mikulaš Hoffman's inventory from 1600

18 Mandelena Hvězdová (New Town, 1599/160o), AHмP 1210, fol. 156r; Veronika Dirixová (Old Town, 1700), AHMP 1179, fol. 394v.

19 For the Italian context, see references to rosaries made of different materials in King R., "The beads with which we pray are made from it': devotional ambers in early modern Italy", in de Boer W. - Göttler C. (eds.), Religion and the senses in early modern Europe (Leiden: 2012) 153-176; Galandra I. - Laven M., "The Material Culture of Piety in the Italian Renaissance: Re-touching the Rosary", in Richardson - Hamling - Gaimster (eds.), Routledge Handbook 338-353, here 340; This practice was not only limited to prayer beads, see also coral talismans in Renaissance Italy. Musacchio J., "Lambs, Coral, Teeth, and the Intimate Intersection of Religion and Magic in Renaissance Tuscany", in Montgomery S. Cornelison S. (eds.), Images, Relics, and Devotional Practices in Medieval and Renaissance Italy (Tempe: 2005) 139-156, here 151. Further research on the difference in materials noted in the Prague inventories may produce interesting results.

20 Also see examples in the German and Italian contexts in 50o Jahre Rosenkranz: 1475 Köln 1975 (Cologne: 1976) 198; Lightbown, Medieval European Jewellery 353; Schiedermair W., "Der Rosenkranz als Amulett", in Frei U. - Bühler F. (eds.), Der Rosenkranz: Andacht, Geschichte, Kunst (Bern: 2003) 200; Musacchio, "Lambs, Coral, Teeth" 151 fn. 45. 


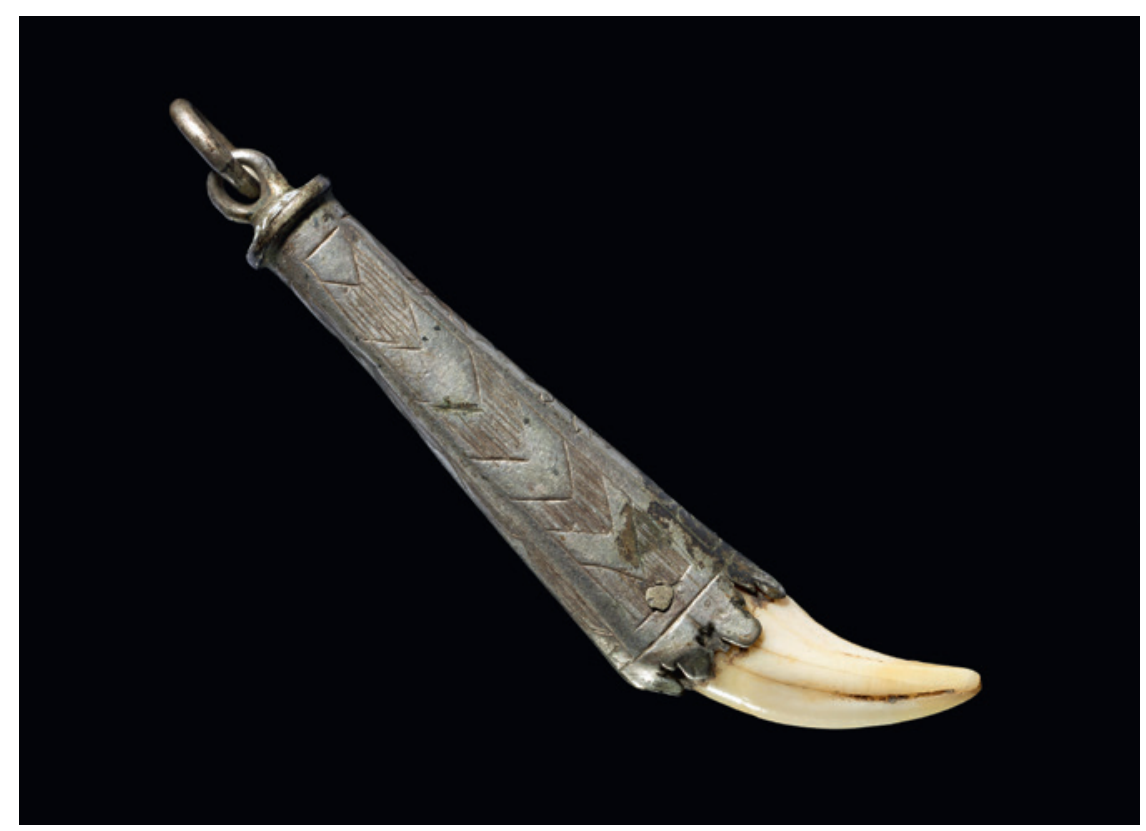

FIGURE 10.2 Tooth amulet (seventeenth century). Tooth, silver, $7 \mathrm{~cm}$. British Museum (OA.1382)

IMAGE (C) THE TRUSTEES OF THE BRITISH MUSEUM

noted a paternoster made of 'some silver beads and a tooth of a wolf and two teeth of a lynx.' ${ }^{21}$ Few intact paternosters survive from this period in spite of the large numbers of prayer beads attested to in the inventories, particularly around 1600. Many would undoubtedly have been repurposed into beaded jewellery over subsequent years, thus losing their distinctive ordered format that helped the devotee to count out their prayers. However, we can imagine how the wolf's tooth amulet may have been attached through the example of extant items, such as the tooth amulet in the British Museum [Fig. 10.2]. It is a relatively simple item set in silver and thought to be of German origin. ${ }^{22}$ The engravings of chevrons and diamond shapes on the metal are plain and quite roughly cut and the item is held together by a metal pin hammered through the tooth. This item could have been threaded onto a set of beads by its simple loop at the top.

21 Mikulaš Hoffman (Lesser Town, 1600), AHMP 1217, fol. 13or; in 1600 fifteen out of forty paternosters mentioned in the inventories for that year included groš or coins that may have been used as lucky charms.

22 See other examples in Hansmann - Kriss-Rettenbeck, Amulett und Talisman 102-103. 
These practices of using amulets and amuletic matter alongside and integrated with more standard religious objects were shared across confessions. Previous studies have perceived the separation of magic from religion to have been a distinctive feature of Protestantism. ${ }^{23}$ However, in the multiconfessional context of Prague in the early seventeenth century, charms and amulets were possessed alongside both Catholic and Protestant texts and objects. Kúndrat the clockmaker owned charms alongside paternoster prayer beads and Lutheran texts. Mikulaš Hoffman's paternoster beads with teeth were kept alongside a Lutheran sermon book. These two examples also reveal a more general phenomenon not only of owning items that mixed the amuletic with standard devotional objects, but also of owning items from both Catholic and Protestant confessions in the early seventeenth century. ${ }^{24}$

Other inventories reveal how tooth amulets were owned across confessions. In the 1610 inventory of Kateřina Kutnaúrová z Alberndorff 'two beavers' teeth set in silver' and an amulet of crystal in a silver setting were kept alongside jewellery that implied her Catholic faith, including a gold medal with a crucifix and a jewel made of gold, table-cut diamonds and rubies depicting the pelican in her piety. The pelican in her piety was a popular image in seventeenthcentury Prague. It showed the pelican wounding her breast in order to feed her young and symbolized Christ the Redeemer's sacrifice. On the Protestant side, in 1620 the glassworker Petr Agler possessed 'four old wolves' teeth' along with Lutheran texts. ${ }^{25}$ This inventorial evidence crucially reveals that both faiths used amulets to engage divine power.

Such evidence underlines how Protestantism was not a religion devoid of 'magic' in everyday practice. Rather, there were many ways in which Protestants 'held onto' and developed new so-called enchanted practices. ${ }^{26}$ In Protestant Germany, a bible might be stored under the pillow to keep the sleeper safe and woodcut images were worn in pouches around the neck to ward off danger. Even objects that were not directly attached to religious texts and images

23 Primarily represented in Thomas, Religion and the Decline of Magic 58-89.

24 Kúndrat Šteffenaúr (New Town, 1635), AHMP 1214, fol. 199r, fol. 205r; Mikulaš Hoffman (Lesser Town, 1600), AHMP 1217, fol.13or. Explored further along with the nuances of the various Protestant faiths in Prague in Ivanič, Religious Materiality; on rosary beads, healing and confessional change, see also King R., "The Reformation of the Rosary Bead: Protestantism and the Perpetuation of the Pater Noster", in Ivanič S. - Laven M. - Morrall A. (eds.), Religious Materiality in the Early Modern World (Amsterdam: forthcoming).

25 Kateřina Kutnaúrová z Alberndorff (Lesser Town, 1610/15), AHMP 2135, fol. A5r; Petr Agler (Old Town, 1620), AHMP 1175, fol. 179r.

26 Cameron, Enchanted Europe; Clark, Thinking with Demons; Blaen, Medical Jewels 64, 324; Lotz-Heumann U., "The Natural and Supernatural", in Rublack U. (ed.), The Oxford Handbook of Protestant Reformations (Oxford: 2016) 688-707. 
could be used for miraculous effect. Bread troughs could be used in conjunction with a spell to redirect wind and put out a fire and axes could mark the threshold for protection of newly-weds, new mothers and the deceased. ${ }^{27}$ From this lay perspective, as Ulinka Rublack has noted, the Protestant Reformation "was not a "disenchanted" religion [...] which drew clear and tight boundaries between "religion" and "magic", but rather, people 'expected religion to protect them against misfortune. ${ }^{28}$ Enchantment has thus been reinscribed into the Protestant narrative. Whilst these studies have argued for Protestant enchantment and in some cases made subtle distinctions between Protestant and Catholic types of recourse to the divine, recent work has found that men and women of these different confessions also engaged in a 'shared cosmology.' ${ }^{29}$ Both Protestants and Catholics united in an understanding of nature advanced by early modern natural philosophers. ${ }^{30}$

Examining lived religious practices, historians have long established the connections that existed between religion and so-called magic in daily life. They describe the lines or 'boundaries' between magic and religion as 'fine', 'blurred' and 'shifting' in this period. ${ }^{31}$ Others have described separate but interrelated, 'overlapping', or 'intersecting' systems of belief of astrology, witchcraft, and magical healing in parallel with religion. ${ }^{32}$ However, such vocabulary still suggests an underlying separation of 'religion' and 'magic'. Recent work has cautioned against putting 'artificial boundaries on a fluid system. ${ }^{33}$ Here, I suggest the need to go one step further. ${ }^{34}$ Investigating materiality - in particular here, the prominence and use of natural matter in amulets alongside early

27 Scribner R., Religion and Culture in Germany (1400-180o), ed. L. Roper (Leiden: 2001) 287, 317, 341; Scribner R., For the Sake of Simple Folk: Popular Propaganda for the German Reformation (Cambridge: 1981) 5 .

28 Rublack U., Reformation Europe (Cambridge: 2005) 156.

29 Lotz-Heumann, "The Natural and Supernatural" 689-690; distinctions between confessions highlighted for example in Scribner, Religion and Culture 326, 287-301.

30 Further work needs to be done to compare the place of Jewish understanding of nature: see Trachtenberg, Jewish Magic and Superstition 132-152, especially 135-6; and Pe'amim 85 (2000).

31 Musacchio, "Lambs, Coral, Teeth" 156; Walsham A., "The Reformation and the 'Disenchantment of the World' Reassessed", The Historical Journal 51, 2 (2008) 497-528, here $501-502$.

32 Thomas, Religion and the Decline of Magic ix, 761; Greyerz K. von, Religion and Culture in Early Modern Europe, 1500-180o (Oxford: 2008) 6.

33 Lotz-Heumann, "The Natural and Supernatural" 690.

34 In what follows, I build on Kieckhefer's idea of rationality in magic but explore its early modern contexts, its particular religious dimensions and how amulets give unique access to how these ideas may have circulated amongst the laity. Kieckhefer, "The Specific Rationality". 
modern views about the natural world - reveals that these were not flowing, overlapping systems of belief, but a unified system of the divine with an internal structure in which God pervaded all elements. There was logic to how the divine could work through these shards of stone or animal matter. From a lay perspective the use of amulets and precious stones was not 'enchantment', but stemmed from a belief in a cosmology in which the divine was present in and could work through the natural world. To reveal the intersections and connections of this system, Part 2 more closely examines contemporary understandings of natural philosophy and the materiality of these amulets.

\section{Amulets as Instruments of Divine Power}

Stones and natural matter had long been believed to have specific virtues. Pliny's Naturalis Historia (c.77-9 AD), and De Mineralibus and De Occultis Naturae by Albertus Magnus (1193-1280) outlined such virtues. These early treatises were printed and widely distributed in the sixteenth century. Copies even occasionally appeared in the libraries of Prague burghers. ${ }^{35}$ Furthermore, numerous new lapidaries in the early modern period revisited, tested and promulgated the virtues of protection and healing that they had claimed as part of a reinvigorated interest in how the natural world worked. ${ }^{36}$

In 1609 one of the most significant works on the subject was produced in Prague. Anselmus Boetius de Boodt (1550-1632) became 'physician in ordinary' to Rudolf II in 1584. Whilst in Prague, he published Gemmarum et Lapidum Historia, containing around 600 minerals with their properties including their 'virtues'. ${ }^{37}$ In Book 1, Chapter 25, de Boodt explained how the powers of stones worked. He stressed that the stones themselves could only work in a natural or elemental way, producing effects such as magnetism, or medical effects like staunching blood. He stressed that the stones themselves could not produce what he called 'supernatural effects'. In terms of causation, anything supernatural that appeared to happen through gems or stones was not due to them, but to God or to a good or evil spirit subject to him. Thus, he disputed

35 For example, Pliny's Natural History in Dorota Loselius (Old Town, 1635), АнмР 1176, fol. 111v; De Occultis Naturae attributed to Albertus Magnus in Dorotha Armpachová (Old Town, 1600), AHMP 1174, fol. 110r.

36 Evans, Magical Jewels 140-155; Blaen, Medical Jewels 120-137, and passim.

37 Boodt Anselmus Boetius de, Gemmarum et Lapidum Historia (Hannover, Typ. Wechelianis apud C. Marnium et heredes J. Aubrii: 16o9); see also, Evans, Magical Jewels 152; Duffin C.J. - Moody R.T.J. - Gardner-Thorpe C. (eds.), A History of Geology and Medicine (London: 2013) 30. 
the ability of stones themselves to darken the sun, make the wearer invisible, make men rich, eloquent, happy and secure, or detect adultery; anything that 'of nature cannot be done using ordinary instruments.' ${ }^{38}$ The natural matter was only used as an instrument through which to manifest the effect. All the various powers attributed to precious stones were to be tested and investigated throughout the book, but de Boodt's overriding proposition was that only their 'natural' powers were automatically efficacious.

Whilst de Boodt wrangled with what effects stones produced and how, it is important to note that his work was still set within an overarching belief in which the natural world itself was imbued with divine power. God had created and designed the universe, and he was thus ultimately the architect of the natural powers of stones. ${ }^{39}$ God's role in the power of natural matter was also tied to an early modern worldview based on Paracelsian philosophy. Starting in the fifteenth and sixteenth centuries natural philosophers such as Marsilio Ficino (1433-1499), Heinrich Cornelius Agrippa von Nettesheim (1486-1535), and Theophrastus Paracelsus (1493-1541) sought to understand the universe as a complex but ultimately 'rational' system. ${ }^{40}$ These philosophers are often linked with early modern 'natural magic', and Neoplatonic and Hermetic thinking about the harmony of the universe that continued to have influence into the seventeenth century. ${ }^{41}$ They engaged with the natural world as God's creation (following Genesis), but also used their skills as natural philosophers to uncover God's secrets: to find exactly how divine influences worked through and within nature. ${ }^{42}$ Part of this endeavour was to seek explanation of natural causes through uncovering 'deep structures' in the natural universe. ${ }^{43}$ Cosmologies, universal harmonies, sympathies and systems of

38 De Boodt, Gemmarum et Lapidum Historia 42-43 in Evans, Magical Jewels 152; compare similar formulations in Gorkum Heinrich von, Tractatus de supersticiosis quibusdam casibus (Esslingen, Conrad Fyner: 1473) $3^{\mathrm{r}}-5 \mathrm{~V}$ and Paracelsus Theophrastus, "Archidoxis Magicae Libri vii", in Opera Omnia, 3 vols. (Geneva, Joannes Antonius \& Samuel de Tournes: 1658) vol. 2, 695 quoted in Cameron, Enchanted Europe 110 and 71-73 respectively.

39 De Boodt, Gemmarum et Lapidum Historia Book 1, Chapter 8.

40 Tambiah, Magic, Science, Religion; Cameron, Enchanted Europe 2; Kieckhefer, "The Specific Rationality" 820-821; Yates, Giordano Bruno 62-151.

41 Clark, Thinking with Demons 215, 222; Yates, Giordano Bruno 1-189; Evans, Rudolf 197; Gouk P., "Natural philosophy and natural magic", in Fučíková E. (ed.), Rudolf II and Prague: The Court and the City (London: 1997) 231-237.

42 Smith P., The Body of the Artisan: Art and Experience in the Scientific Revolution (Chicago: 2004); on nature as a divine book, see Walsham A., The Reformation of the Landscape: Religion, Identity, and Memory in Early Modern Britain and Ireland (Oxford: 2011) 327-394.

43 Daston L. - Park K., Wonders and the Order of Nature, 1150-1750 (New York: 1998) 163; Daston L., 'The Nature of Nature in Early Modern Europe', Configurations 6, 2 (1998) 149-172. 
correspondences gave reason to the way that certain natural matter had the ability to act powerfully in specific ways. ${ }^{44}$

It is difficult to gauge to what extent the nuanced arguments of natural philosophy were taken up at a 'lay' level. The natural world was broadly understood by the laity to be deeply connected to the divine in this period..$^{45}$ Many of the meanings of matter in the early modern period reflected the idea of correspondences in a structured cosmology created by God. For example, folklore sources suggest that wolves' teeth may have been used as 'hunting charms' bringing good luck for a successful kill, or alternatively a tooth worn around the neck might work apotropaically against all wolf-like animals. Sewn into the cap of a first-born it could ferociously protect against the evil eye. A wolf's tooth could also act as an amulet against toothache, lunacy, fear of the night and, powdered, it could banish vertigo. ${ }^{46}$ Wolves' teeth had these effects because they were imbued - in microcosm - with the powerful qualities of the animal. It was believed that God himself had given wolves the virtues of being nocturnal, fierce, good hunters, strong and unafraid of the steep mountainous environments they inhabited. Amulets encapsulated the powerful resonances in God's natural world, and were thus treated as an integral part of an extensive and connected religious culture.

In addition, some lapidaries and vernacular treatises were produced for a 'popular' readership. ${ }^{47}$ Recent studies have also shown how artisans, apothecaries and marketplaces were potential mediators of current intellectual thinking and fashions. ${ }^{48}$ Knowledge might be shared in unexpected ways and in varied combinations by such intermediaries and in such spaces. For example,

44 Tambiah, Magic, Science, Religion 30; Yates, Giordano Bruno 151; Clark, Thinking with Demons 222; Thomas, Religion and the Decline of Magic 224; Musacchio, "Lambs, Coral, Teeth" 153; Scribner, Religion and Culture 321; compare also Blaen, Medical Jewels 120. Crowther-Heyck K., "Wonderful Secrets of Nature: Natural Knowledge and Religious Piety in Reformation Germany", Isis 94, 2 (2003) 253-273.

46 Handwörterbuch des deutschen Aberglaubens, ed. [...] bächtold stäubli[...]. 10 vols. (Berlin - Leipzig: 1927-42) vol. 9, 768, 778, 781; for further use as 'teething sticks' and comparison with coral versions, see Ajmar-Wollheim M., "Geography and the environment", in Cavallo S. - Evangelisti S. (eds.), A Cultural History of Childhood and Family in the Early Modern Age (Oxford: 2010) 79; Krohn D. - Miller P. (eds.), Dutch New York between East and West: The World of Margrieta van Varick (New Haven: 2009) 244; Pointon M., Brilliant Effects: A Cultural History of Gem Stones and Jewellery (New Haven: 2009) 130-131.

47 Blaen, Medical Jewels 6-7, 79-82; for Italy see Cavallo S., Artisans of the Body in Early Modern Italy: Identities, Families and Masculinities (Manchester: 2007) 86 fn. 45. See also discussion of 'popular' understandings of theories in Kieckhefer, "The Specific Rationality" $835-836$.

48 Cavallo, Artisans of the Body; Eamon W., "Markets, Piazzas, and Villages”, in Park K. - Daston L. (eds.), The Cambridge History of Science, Vol. 3: Early Modern Science (Cambridge: 2006) 
Sandra Cavallo has suggested that jewellers employed medical knowledge of the virtues of stones when advising clients on their purchases. ${ }^{49}$ It is perhaps not too much of a stretch to suggest that they may simultaneously have alluded to some of the theories about why certain items had these effects. The ownership of a wide variety of stones and animal matter suggests that men and women eagerly engaged with an understanding of the natural world in which it was imbued with power that could protect them against the exigencies of daily life, even if complex theories regarding how God exercised these powers through natural materials evaded full comprehension. As the keeping of religious items with amulets shown above suggests, using amulets was not considered dangerous, superstitious nor magical, but an everyday practice that could sit easily alongside supplication of the divine through telling prayer beads or praying with a crucifix.

Amulets made of natural matter allowed a wide range of social strata to access divine power. Although precious and semi-precious stones were expensive, they could be fashioned into tiny amulets available to men and women of modest means. ${ }^{50}$ A minuscule malachite pendant held in the Victoria \& Albert Museum [Fig. 10.3] shows just how simple an amulet might be. This item is one example of many 'heart amulets' usually kept in museum storage. It is tiny, measuring just $1.6 \mathrm{~cm}$ in length and width. Facing the body, the side stamped with the heart would have acted as a secondary, hidden aspect, probably known only to the wearer. The piece of stone has not been cut down to make a perfect heart form out of it, but rather metal has been used to fill gaps and therefore a greater part of the original stone has been preserved. Lapidaries attest that malachite was thought to protect against the evil eye, thunder, lightning and the soul falling into disorder, to strengthen the stomach and to save children from harm. ${ }^{51}$ The extant item shows that even a fleck of the stone was thought to be efficacious and worth setting in silver. Such a modest object would have been obtainable by a wide clientele.

Burgher inventories reveal that gems were also widely accessible in the form of rings. Jan Petr's inventory from 1625 lists 22 rings in which the scribe identified turquoise, diamond, hyacinth and emerald, as well as 'red and blue

206-223, here 210-211, 219; Welch E., "Art on the Edge: Hair and Hands in Renaissance Italy", Renaissance Studies 23, 3 (2009) 241-268: 256; Daston, Wonders 172.

49 Cavallo, Artisans of the Body $77-78$.

5o Contrast claim by Blaen, Medical Jewels 58-59, 239-252; Kieckhefer, "The Specific Rationality" 833 .

51 De Boodt, Gemmarum et Lapidum Historia 133; Nicolas Thomas, A Lapidary, Or the History of Pretious Stones (Cambridge, Thomas Buck: 1652), 145-146. 

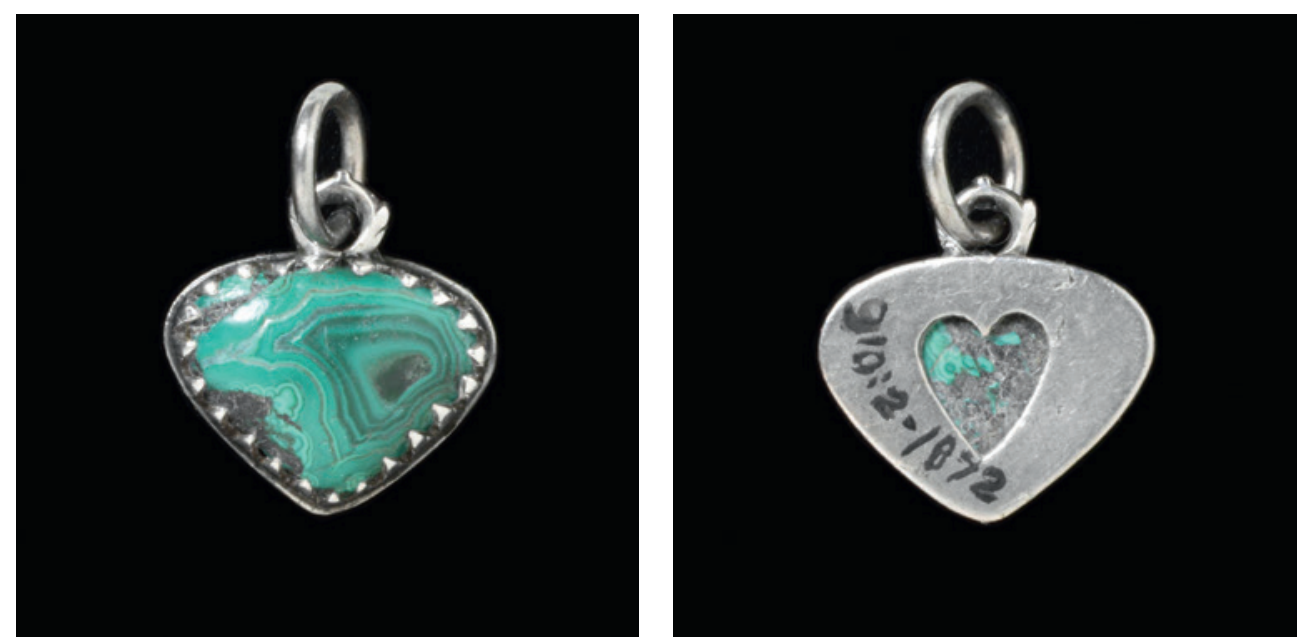

FIGURE 10.3 Malachite heart pendant, Bavarian (eighteenth century). Malachite, silver, $1.6 \mathrm{~cm}$. Victoria and Albert Museum (M.224-1975)

IMAGE (C) VICTORIA AND ALBERT MUSEUM, LONDON

stones' which were likely to have been fake paste gemstones. ${ }^{52}$ Although small items, rings set with stones were thought to be equally effective as pendant amulets in channelling natural powers. The author of the French version of de Boodt's Gemmarum attests to the use of a ruby ring to predict a death. ${ }^{53}$ Like the malachite pendant, rings could incorporate merely a tiny shard of material to make them efficacious. A ring in the Museum of Decorative Arts in Prague from around 1600 showcases a turquoise stone in a pretty, enamel-decorated (Schwartzornament) setting [Fig. 10.4]. Turquoise was a popular stone for marriage rings as it was believed to restore love between husband and wife. ${ }^{54}$ The stone is not a 'perfect' specimen nor brilliantly crafted, and it is encased roughly in the gold setting. The dark oxidized veins across its face are not incorporated artistically, but as they happened to occur. Furthermore, an attempt to smooth the stone prior to setting it in gold has resulted in surface cracks along those lines. There was often an attempt to fashion these imperfect fragments of stone into pretty pieces of jewellery, but the overriding priority for craftsmen

$5^{2}$ Jan Petr (Old Town, 1625), AHмP 1174, fol. 339v; see also extensive collections in Jiř́ Gebuštrey (Old Town, 1600), AHMP 1174, fol. 122r and Anna Kutovcová (New Town, 160o), AHMP 1208, fol. 129v.

53 Thank you to Andrew Morrall for drawing my attention to this case in the French version of de Boodt's Gemmarum et Lapidum - Toll André, Le Parfaict Ioailler: ou Histoire des Pierreries (Lyon, Jean-Antoine Huguetan: 1644) 183-184.

De Boodt, Gemmarum et Lapidum Historia 137. 


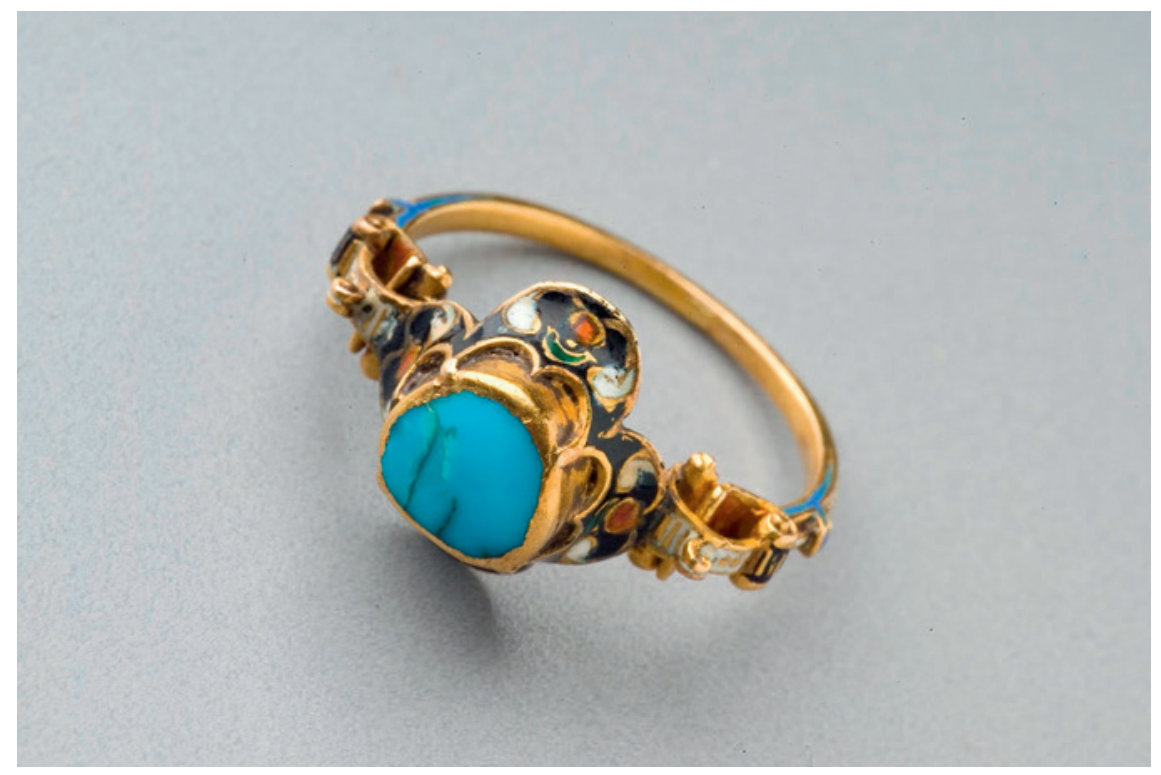

FIGURE 10.4 Turquoise ring, German? (c. 160o). Turquoise, gold, enamel. Museum of Decorative Arts in Prague (UPM 101.537)

IMAGE (C) MUSEUM OF DECORATIVE ARTS IN PRAGUE

seems to have been to include as much of the substance as possible in the amulet, no matter how low the quality of the stone: it was the presence of the matter that counted.

\section{Conclusion}

The tiny and inconspicuous amulets that shelter in the storage rooms of many museums are a vital missing link for historians interested in lived religion. Amulets - though often sidelined as unimportant and inelegant shards of raw material - provide us with a way to understand and connect some of the most pressing debates of recent years. They show how a narrative of disenchantment and the division between religion and magic were absent in much of everyday lived religious culture. Rather, the natural material they incorporated acted as an interface that fused ideas about the divine and the natural world. They allow us to see how debates about religion and magic must be triangulated with those of natural philosophy. Instead of a blurred, 'fluid system', we can perceive in these practices around amulets the traces of a highly reasoned worldview about the structure of the universe and how the divine worked 
through it. Finally they reveal how such intellectual beliefs permeated all social strata. At every level and across confessions, men, women and children could share a fundamental understanding of the divine in nature - perhaps not through a nuanced intellectual grasp of the theory, but through a material practice: by carrying a little piece of stone or tooth on their person.

Amulets were part of a wide spectrum of everyday religious objects kept in the home that allowed access to the divine. They were used alongside Catholic sacramentals, Protestant bibles, spells, or written talismans, and show that it was not just artificial objects that could 'order' the cosmic world, or negotiate the exigencies of daily life. ${ }^{55}$ Natural matter itself had these capabilities and acted as a resonant interface with divine powers that were embedded in the material natural world since Creation.

Recent work that seeks to understand religion and natural philosophy in more deeply cultural terms allows us to reintegrate amulets into the history of this period and understand why they were so ubiquitous and important in daily life and so commonly recorded in Prague burghers' inventories. Amulets should no longer be forced into the problematic categories of secular, superstitious, folkloric or magical. Rather, placed at the centre of historical enquiry as objects integrally associated with the divine in the natural world, they can cast new light on everyday religion.

\section{Bibliography}

\section{Literature}

Blaen T., Medical Jewels, Magical Gems: Precious Stones in Early Modern Britain: Society, Culture and Belief (Crediton: 2012).

Cameron E., Enchanted Europe: Superstition, Reason, and Religion, 1250-1750 (Oxford: 2010).

Clark S., Thinking with Demons: The Idea of Witchcraft in Early Modern Europe (Oxford: 1997).

Crowther-Heyck K., "Wonderful Secrets of Nature: Natural Knowledge and Religious Piety in Reformation Germany", Isis 94, 2 (2003) 253-273.

Daston L. - Park K., Wonders and the Order of Nature, $1150-1750$ (New York: 1998).

Evans J., Magical Jewels of the Middle Ages and the Renaissance, particularly in England (Oxford: 1922).

55 Compare Scribner R., Popular Culture and Popular Movements in Reformation Germany (London: 1987) 1-2; Gentilcore, From Bishop to Witch 94; Scribner, Religion and Culture 299, 323, 349 . 
Gouk P., "Natural philosophy and natural magic", in Fučíková E. (ed.), Rudolf II and Prague: The Court and the City (London: 1997) 231-237.

Hansmann L. - Kriss-Rettenbeck L., Amulett und Talisman. Erscheinungsform und Geschichte (Munich: 1966).

Ivanič S., "Early modern religious objects and materialities of belief", in Richardson C. - Hamling T. - Gaimster D. (eds.), Routledge Handbook of Material Culture in Early Modern Europe (Abingdon: 2016) 322-337.

Kieckhefer R., "The Specific Rationality of Medieval Magic", The American Historical Review 99, 3 (1994) 813-836.

Lotz-Heumann U., "The Natural and Supernatural", in Rublack U. (ed.), The Oxford Handbook of Protestant Reformations (Oxford: 2016) 688-707.

Musacchio J., "Lambs, Coral, Teeth, and the Intimate Intersection of Religion and Magic in Renaissance Tuscany", in Montgomery S. - Cornelison S. (eds.), Images, Relics, and Devotional Practices in Medieval and Renaissance Italy (Tempe: 2005) 139-156.

Reinburg V., French Books of Hours: Making an Archive of Prayer, c. 1400-160o (Cambridge: 2011).

Thomas K., Religion and the Decline of Magic: Studies in Popular Beliefs in Sixteenth and Seventeenth Century England (London: 1979 [1971]).

Walsham A., "The Reformation and the 'Disenchantment of the World' Reassessed", The Historical Journal 51, 2 (2008) 497-528.

Yates F., Giordano Bruno and the Hermetic Tradition (London: 1964). 